\title{
DATA INTEGRATION ACQUIRED FROM MICRO-UAV AND TERRESTRIAL LASER SCANNER FOR THE 3D MAPPING OF JESUIT RUINS OF SÃO MIGUEL DAS MISSÕES
}

\author{
M. L. L. Reiss ${ }^{a}$, R. S. da Rocha ${ }^{b}$, R. S. Ferraz ${ }^{\text {c }}$, V. C. Cruz ${ }^{\text {d }}$, L. Q. Morador ${ }^{d}$, M. K. Yamawaki ${ }^{\text {d }}$ E. L. S. Rodrigues, J. O. Cole ${ }^{\text {, }}$, \\ W. Mezzomo ${ }^{\mathrm{d}}$ \\ ${ }^{\text {a }}$ LAFOTO - Laboratory of Photogrammetry Research, Dept. of Geodesy, Institute of Geoscience, UFRGS - Federal University of \\ Rio Grande do Sul, Brazil - mario.reiss@ufrgs.br, lafoto@ufrgs.br \\ ${ }^{\mathrm{b}}$ LACAP - Laboratory of Applied Cartography, Dept. of Geodesy, Institute of Geoscience, UFRGS - Federal University of Rio \\ Grande do Sul, Brazil - ronaldo.rocha@ufrgs.br \\ ${ }^{\mathrm{c}}$ Graduation in Remote Sense, State Centre for Research on Remote Sensing and Meteorology, UFRGS - Federal University of Rio \\ Grande do Sul, Brazil - rferraz1980@gmail.com

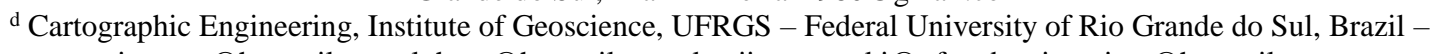 \\ viny.poa@hotmail.com, luhqm@hotmail.com, kenji.yamawaki@ufrgs.br, tiquetinrs@hotmail.com

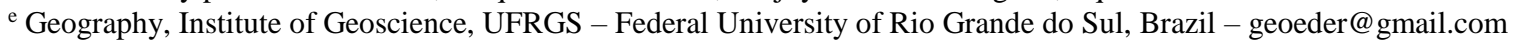

\section{Commission V, WG V/2}

KEY WORDS: Photogrammetry, Micro-UAV, Fixed and rotary wings, Terrestrial LIDAR, Cultural heritage.

\begin{abstract}
:
The Jesuit Missions the Guaranis were one of the great examples of cultural, social, and scientific of the eighteenth century, which had its decline from successive wars that followed the exchange of territories domain occupied by Portugal and Spain with the Madrid Treaty of January 13, 1750. One of the great examples of this development is materialized in the ruins of 30 churches and villages that remain in a territory that now comprises part of Brazil, Argentina and Paraguay. These Churches, São Miguel das Missões is among the Brazilian ruins, the best preserved. The ruins of São Miguel das Missões were declared a UNESCO World Cultural Heritage in 1983 and the Institute of National Historical Heritage (IPHAN) is the Brazilian Federal agency that manages and maintains this heritage. In order to produce a geographic database to assist the IPHAN in the management of the Ruins of São Miguel das Missões it was proposed a three-dimensional mapping of these ruins never performed in this location before. The proposal is integrated data acquired from multiple sensors: two micro-UAV, an Asctec Falcon 8 (rotary wing) and a Sensefly e-Bee (fixed wing); photos from terrestrial cameras; two terrestrial LIDAR sensors, one Faro Focus 3D S-120 and Optec 3D-HD ILRIS. With this abundance of sensors has been possible to perform comparisons and integration of the acquired data, and produce a 3D reconstruction of the church with high completeness and accuracy (better than $25 \mathrm{~mm}$ ), as can be seen in the presentation of this work
\end{abstract}

\section{INTRODUCTION}

\subsection{Working Context}

The Jesuit ruins of San Miguel Mission is the third architectural complex listed as UNESCO World Heritage in 1983. Before that, were the Historical City of Ouro Preto, in the state of Minas Gerais in 1980, and the Olinda Historical Center in the state of Pernambuco in 1982. As a National Cultural Heritage, the ruins of São Miguel das Missions are listed since 1938, just one year after the creation of the Instituto do Patrimônio Histórico e Artístico Nacional (IPHAN). In Brazil it is the responsibility of IPHAN protect and promote the cultural heritage of the country, ensuring their permanence and enjoyment for future generations (IPHAN, 2014).

In the region of the Missions in the State of Rio Grande do Sul, there were seven villages of the Jesuit Missions of the Guaranis: São Nicolau (the current city of the same name), São Luiz Gonzaga (in the current city of the same name), São Francisco de Borja (in current city of São Borja), São Miguel Arcanjo (in the current city of São Miguel das Missões), São Lourenço de Mártir (in the current city of São Luiz Gonzaga), São João Batista (the current Entre-Ijuís) and Santo Angelo Custódio (in the current city of Santo Angelo). In each of these villages was an eponymous church, and around these churches had their village of Indians and missionaries. These seven village, three were completely overlapped by the expansion of cities where there are São Francisco de Borja, São Luiz Gonzaga and Santo Ângelo Custódio. In the other four villages there are still archaeological remains of churches, and the Church of São Miguel das Missões is the one that still preserves its church structure without roofs and lining the walls. A summary of the history of the Church of São Miguel Arcanjo can be found in IPHAN (2014 b).

Thus, regionally called "Ruins of São Miguel das Missões" are a heritage of great historical significance and tourism for the state of Rio Grande do Sul and Brazil (IPHAN, 2014 b; Leal, 2009). Considering this importance, and in order to assist in the management of the Archaeological Park of São Miguel das Missões, was proposed by UFRGS to the Superintendence of IPHAN in the state of Rio Grande do Sul (IPHAN-RS) a threedimensional modeling of the Church and a mapping of the park area. It had long since other surveying were not performed in the park, which caused the lack of updated measurements. Thus, it was signed an agreement between the IPHAN-RS and the UFRGS, through its Research Laboratory of Photogrammetry LAFOTO. The proposal was to apply the best techniques according to the resources available at the University.

For the mapping of the park were used: 
- A terrestrial laser scanning system (TLS) ILRIS-HD 3D Optech, with nominal accuracy of up to $7 \mathrm{~mm}$ for a range of $100 \mathrm{~m}$;

- An unmanned aerial vehicle (UAV), fixed-wing, Sensefly eBee with GSD (Ground Sample Distance);

- Two total stations Topcon 7500, with angular resolution of 5", linear accuracy of $10 \mathrm{~mm}+10 \mathrm{ppm}$ for reflector less measurement and $2 \mathrm{~mm}+2 \mathrm{ppm}$ for measurement with prism;

- Two pairs of GNSS receivers Hiper Lite with horizontal accuracy of $3 \mathrm{~mm}+0.5 \mathrm{ppm}$ and vertical 5 $\mathrm{mm}+0.5 \mathrm{ppm} \mathrm{L} 1+\mathrm{L} 2$;

- Two GNSS receivers GR3 with horizontal accuracy of $3 \mathrm{~mm}+0.5 \mathrm{ppm}$ and vertical $5 \mathrm{~mm}+0.5 \mathrm{ppm} \mathrm{L1}+$ L2;

For the modelling of the Church were used:

- A TLS FARO Focus3D S 120, with nominal accuracy of up to $\pm 2 \mathrm{~mm}$ for a range of 10 to $25 \mathrm{~m}$;

- An UAV with rotary wing, Asctec Falcon 8, with a Nex 7 camera, with nominal focal length of $18 \mathrm{~mm}$, frame size of $24 \times 16 \mathrm{~mm}$, with $6000 \times 4000$ pixels;

- A Canon camera EOS Rebel XSi, with nominal focal length of $20 \mathrm{~mm}$, frame size of $22,28 \times 14,85 \mathrm{~mm}$, with 4272x2848 pixels;

- The same GNSS receivers and total station listed above.

Besides the equipment listed above for surveying, workstations were used containing software for photogrammetric processing (ERDAS LPS, Agisoft Photoscan), TLS processing data (Faro Scene, Polyworks) and integration of photogrammetric and TLS results (ArcGIS, CloudCompare, Geomagic Studio).

The horizontal and vertical expected accuracy for measurements of church facades is $25 \mathrm{~mm}$ or higher. Bearing in mind the park mapping, the horizontal expected accuracy is of $15 \mathrm{~cm}$ and vertical is of $30 \mathrm{~cm}$, considering pictures acquired with an average GSD of $10 \mathrm{~cm}$.

Finally, the information that will be generated will:

- Produce a planialtimetric map, a digital surface model (DSM) and a digital terrain model (DTM) of the park;

- Generate a 3D model of the church, through a fusion of the 3D models coming from close range Photogrammetry and TLS.

All these products will permit to the IPHAN to have more control over their management, maintenance and preservation procedures of the Church and of each remaining artefacts of the park area.

Below we present a theoretical review of some measurement techniques and concepts involved archaeological monuments.

\subsection{Related Work}

Long ago Photogrammetry has been one of the key technologies to measure historical monuments for documentation, preservation and restoration (Albertz 2001).

From the recent advances in stereo image matching procedure, Photogrammetry became easier to be applied in situations where the photos are converging, rotated and have wide variation of scale (Lowe, 2004). Currently, an approach variations developed by Lowe (2004), called SIFT (Scale Invariant Feature Transform) have been implemented by many academic and commercial software, allowing for greater automation of the image matching process, and consequently the orientation and reconstruction processes of photographed objects (Barazzetti et al, 2010). Two examples of commercial software are Agisoft Photoscan and Inpho UASMaster. Other studied commercial software does not mention their methodologies employed. Another widely used algorithm for matching pictures is called SURF (Speeded-Up Robust Features) (Bay et al, 2008; Barazzetti et al, 2010), which is a variant of SIFT (Bay et al, 2008).

It can be argued that the algorithms based on SIFT helped improve the use of Photogrammetry from images obtained by UAVs, and other applications where multiple oblique photographs are acquired. This is due to the great advances in automation of orientation and three-dimensional reconstruction process. On the other hand, this automation is weakened in conventional photogrammetric processing software, designed for vertical photographs. Especially in surveying from fixedwing micro-UAVs, some rotary-wing which have no stabilizing systems of the camera, the acquired pictures have great variation in inclination of the optical axis of the lens system. This is caused by their light weight, the longer susceptible to large derives from its flight path due to wind. The UAVs application to generate DSMs in cultural heritage has been widespread (Remondino et al, 2009; Chiabrando et al, 2011; Themistocleous et al, 2015).

Another very currently used for the acquisition of DSMs cultural heritage technique is based on TLS systems. These systems direct laser beams on the objects of interest, and measuring the flight time of the laser beam to the target, you can determine the distance between the sensor phase center and the target. With multiple measured distances associated with the measurement of the respective horizontal and vertical angles, you can determine a cloud of points representing the DSM of the object of interest in a reference system of local coordinates of the TLS instrument.

According to Staiger (2011), there is no way to identify precisely which was the first TLS that came on the market in the mid-1990s, but the brands Riegel (Austria) and Cyrax (USA) were two of the pioneers in the market. Since then, many other brands, models and measurement techniques have developed and established, and there was the spread of applications. The current system, with its high accuracy and density points, allow geometric evaluations of registered objects, and also information of state of the material objects, by gray intensity of the return pulse signal (Gordon et al, 2001; Gordon et al, 2003). With these features, the application in cultural heritage has great attraction (Herráez et al, 2014; Lubowiecka; 2009).

With the improvement of the quality of correspondence and reconstruction process in the generation of DSMs by Photogrammetry, and the high quality of TLS systems, there are also works by comparing and fusion the results of both (Yastikli, 2007; Grussenmeyer et al, 2008; Kheder et al, 2009; Lerma et al, 2010; Bayram et al, 2015).

Taking into consideration the researched references, it was possible to verify the context in which our work is in the area of the measurement and mapping of cultural heritage by Photogrammetry and TLS. What we are developing is a practical application of new technologies for 3D measurement in an area where a UNESCO World Cultural Heritage Site, located in Brazil. 


\section{OUR WORK}

\subsection{Study Area}

The study area is situated in the city of São Miguel das Missões in the state of Rio Grande do Sul, Brazil, $490 \mathrm{~km}$ from the capital, Porto Alegre (Figure 1).
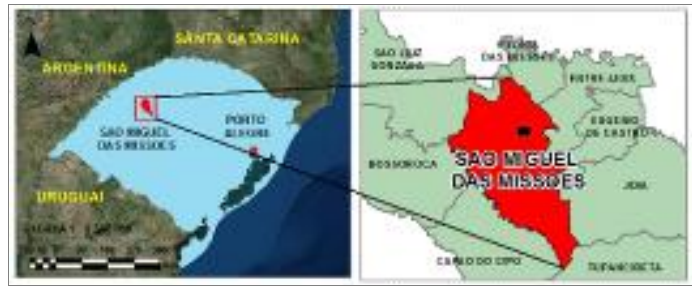

Figure 1 - Study Area: city of São Miguel das Missões.

The São Miguel Arcanjo Park is in a fenced area of approximately 31.9 hectares with a perimeter of $2,309 \mathrm{~m}$ (Figure 2). Several features are present in the area, such as the church, a museum of the Missions, a building maintenance of the park, several stones from the ruins throughout the area, pedestrian paths, adjacent streets, trees and native forest.

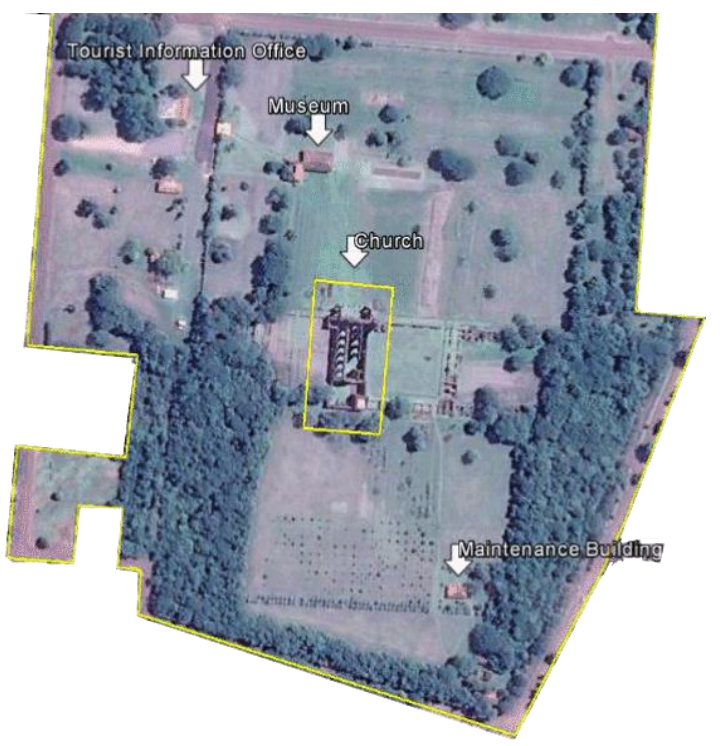

Figure 2 - Study Area: São Miguel Arcanjo Park. (Font: Adapted Google Earth)

\subsection{Geodetic Marks}

The great contribution of the work that we are developing is the use of modern photogrammetric techniques in one of Brazil's historical heritage, in order to enable the documentation, and also give technical and scientific basis for the monitoring of this heritage over time.

To give geodesic basis for measurement activities were implemented and measured geodesic marks, two forced centering pillar (MCSM01 and MSC02) in the frontal region to the Church, and pyramidal in funds to serve as a future reference level (MPSM01) (Figure 3).

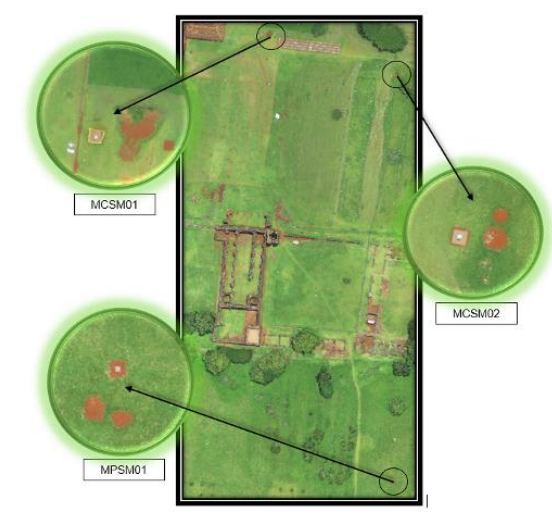

(a)

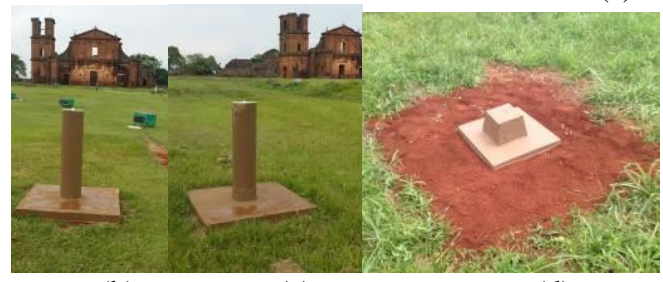

(b)

(c)

(d)

Figure 3 - (a) Location of geodetic marks;(b) MCSM01; (c) MCSM02; (d) MPSM01

The geodesic marks had their coordinate measured with GNSS and referred to the International Geocentric Reference System for South America (SIRGAS - Sistema Internacional de Referência Geocêntrico para as Américas), through the Brazilian Network for Continuous Monitoring (RBMC - Rede Brasileira de Monitoramento Contínuo) of GNSS. An archeological excavation was necessary to perform the implantation of the marks on the park area.

In the facades of the Church, special targets were glued, materializing control points for photogrammetric and TLS surveying. These targets are circular, black and white colors, with a moving part and a fixed part on the wall by a special glue, which does not harm the ruin. This target assembly allows automatic measurement, and the fixed part eternalizes a reference system for the coordinates of the target. This will enable the movement control of the structure that may be suffering from time to time. Coordinate transportation was performed to the targets of the facades from the geodesic marks, by conventional topography (Figure 4).

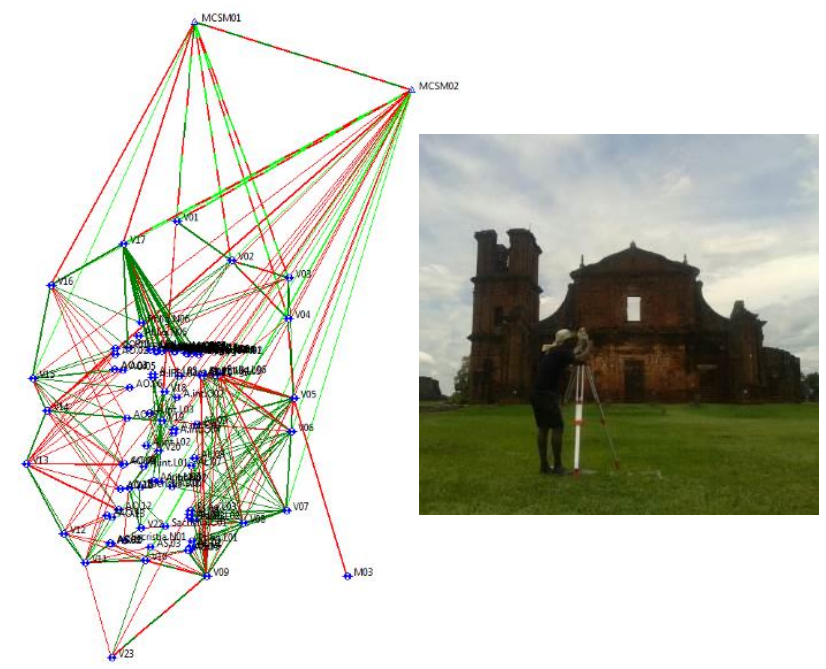

Figure 4 - Topographic Polygonal 


\subsection{TLS Surveying}

We performed two sets of TLS surveying: a first for the generation of the DTM the park area, and one for the production of the DSM of the facades of the Church. For the first, we used the Optech HD 3D ILRIS equipment (Figure 5a), due to their higher range of up to $1500 \mathrm{~m}$. For the second, we used the equipment Faro Focus 3D S, whose range for the best short distances (Figure 5b)

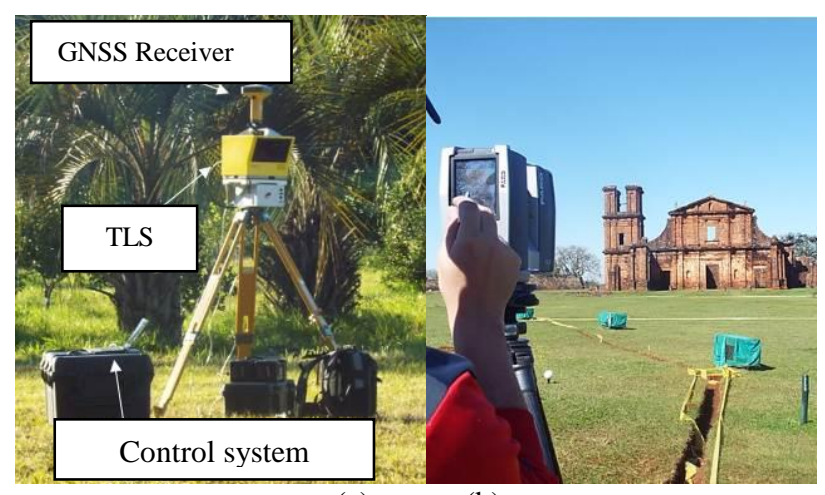

(a)

(b)

Figure 5 - TLS systems: (a) Optech ILRIS 3D HD; (b) Faro Focus 3D S

2.3.1 DTM of the Park: The acquisition of point cloud for the generation park DTM was made based on a distance between points of $60 \mathrm{~cm}$ on the ground. The maximum distance between the TLS stations was $600 \mathrm{~m}$. The point clouds acquired with this equipment had their phase center georeferenced with the help of a GNSS receiver in a relative processing considering the geodesic mark MCSM01. The point clouds were registered considering its phase center as a control point, and this way, the result was a point cloud registered and georeferenced (Figure 6)

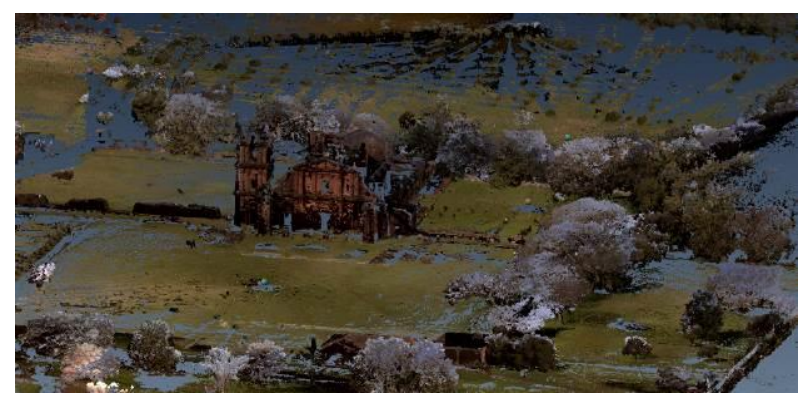

Figure 6 - Point cloud registered and georeferenced acquired from the Optec ILRIS 3D HD

2.3.2 3D Model of the Church: The acquisition of point cloud for the generation of the 3D Model of the Church was performed considering a distance of $5 \mathrm{~mm}$ between points on the ground, to a range of $10 \mathrm{~m}$. The point clouds were registered with each other, and then georeferenced through the known control points and they respective measured on the point cloud of the building facades (Figure 7). A preliminary processing generated from the intensities of the pulse laser make possible to identify the presence of humidity areas, which should be taken care of by IPHAN to maintain the integrity of ruin.

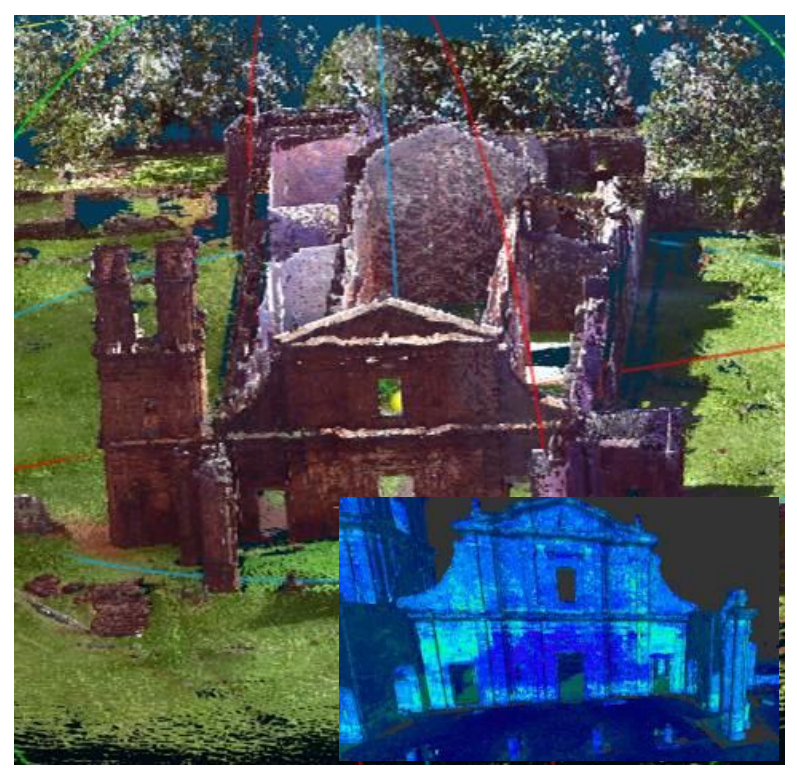

(a)

(b)

Figure 7 - (a) Point cloud registered and georeferenced acquired with Faro Focus 3D HD; (b) Images of gray intensity showing the humidity of the walls of the Church

\subsection{Photogrammetric Surveying}

As the LTS surveying, the photogrammetric was carried out with two goals: the first for the production of the planialtimetric map of the park using a fixed-wing micro-UAV Sensefly eBee (Figure 8a), and the second to create the 3D model of the facades of Church using terrestrial photographs and a rotarywings micro-UAV Asctec Falcon 8 (Figure 8b).

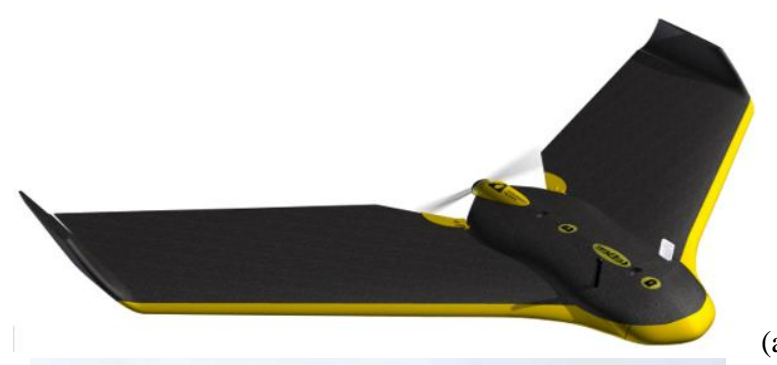

(a)

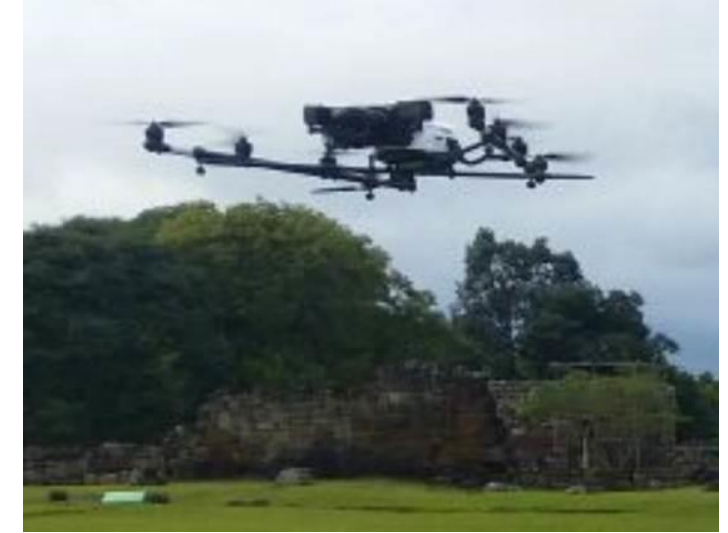

(b)

Figure 8 - UAV systems: (a) Sensefly eBee; (b) Asctec Falcon 8 
2.4.1 Photogrammetric Surveying with Fixes-Wings micro-UAV: In this surveying we considered an average GSD of $10 \mathrm{~cm}$. We have tested other sizes of GSD, but in the work, the best relation of cost-benefit was this size chosen. Our microUAV eBee is equipped with a Canon PowerShot Elph $110 \mathrm{HS}$ camera rotated in the system in $-90^{\circ}$ in the Z-axis, focal length of $4,371 \mu \mathrm{m}$, with pixel size of $1.34 \mu \mathrm{m}$, and $4608 \times 3456$ pixels.

The acquisition of the photographs was in accordance with the flight plan previously defined, considering: the land area covered by the minimum overlap between photos and tracks, and the GSD specified. We pre-signaled 30 points, of which 10 were considered as control points, and 20 checkpoints for quality control. These points were measured on the ground by a GNSS receiver and a relative processing, considering the centering forced mark MCSM01 as a base.

From aerial photographs obtained through the fixed-wing micro-UAV, it was possible generate:

- A map from a features extraction process manually in the computer;

- $\quad$ The DSM area involving the entire park;

- A mosaic of true-orthophotos

Here the data are presented in a single product, a result of the overlap of features on the true-orthophoto (Figure 9).

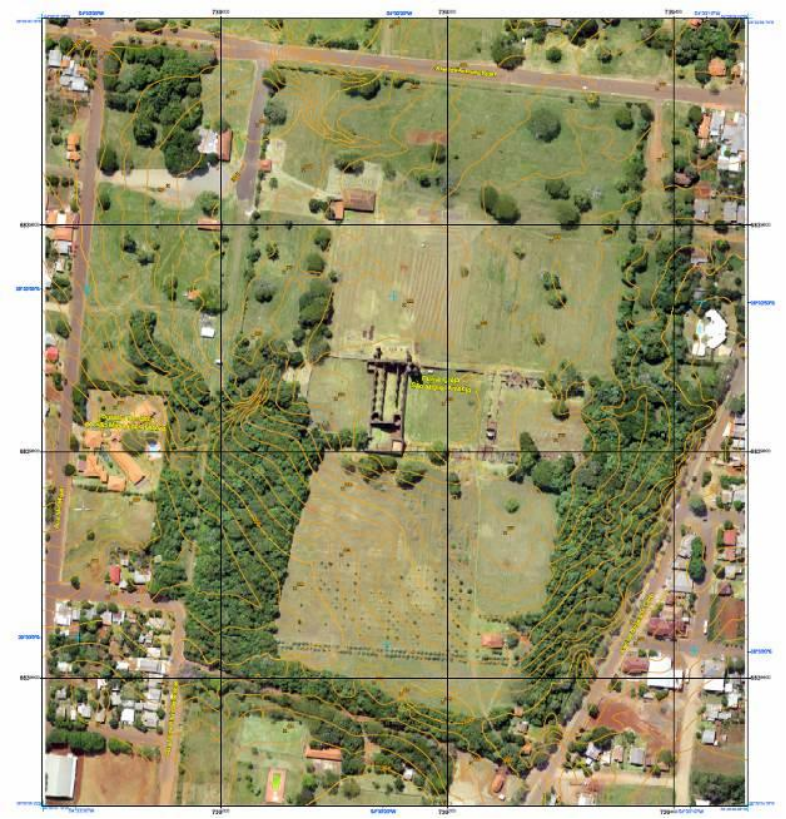

Figure 9 - True-orthophoto map

2.4.2 Photogrammetric Surveying with Rotary-Wings micro-UAV and Terrestrial Pictures: For the production of the Church of the 3D model, terrestrial photographs were acquired (Figure 10a) through the Canon EOS Rebel XSi camera on a tripod, and photos with the micro-UAV Falcon 8, equipped with a Nex-7 camera (Figure 10a).

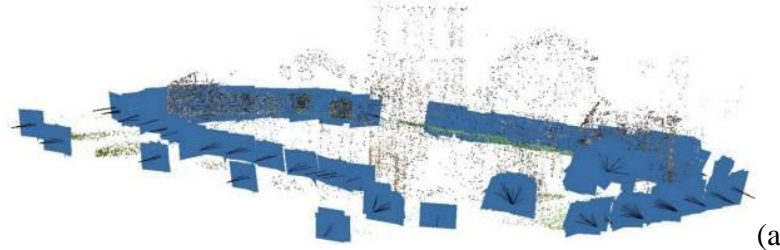

(a)

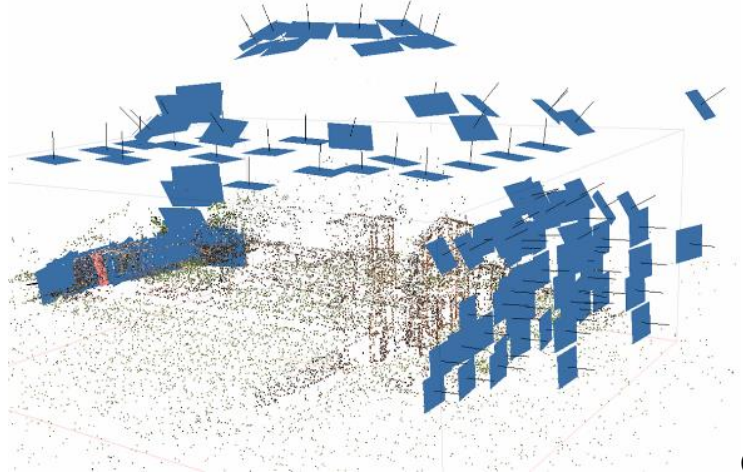

(b)

Figure 10 - Acquired Pictures: (a) Terrestrial Camera; (b) micro-UAV Asctec Falcon 8.

These photographs were combined into a single project, and processed with Agisoft Photoscan software, to determine the exterior orientation parameters (EOP), considering the control points fixed on the walls of the Church. Once determined EOP, is made then the generation of the 3D model and texture, with the result Church realistic representation (Figure 11).

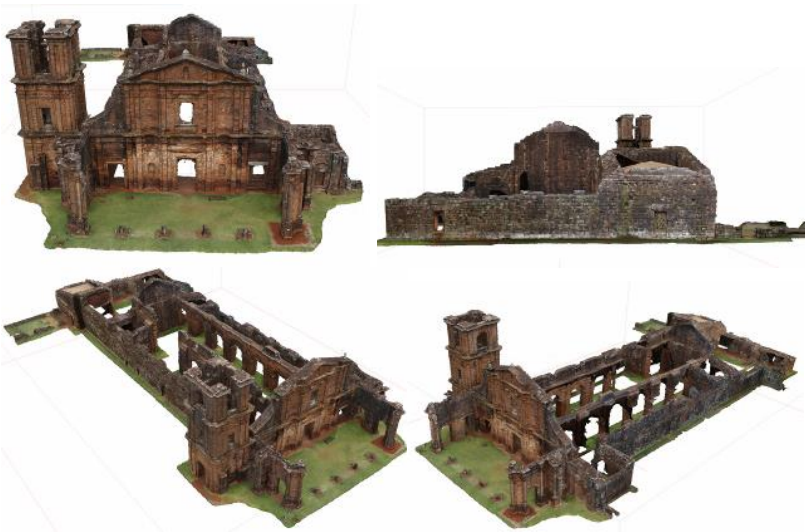

Figure 11 - Views of the 3D Model produced by Photogrammetry on Photoscan.

2.4.3 Fusion of Photogrammetric and TLS Surveying of the Church: A fusion of 3D model by Photogrammetry and TLS for the Church is been created, combining the strengths of each of the methodologies used (Figure 12). 


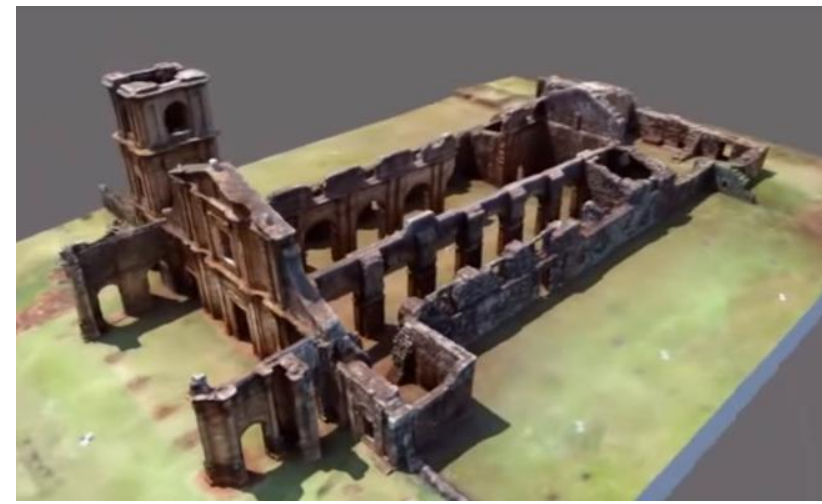

Figure 12 - Fusion of 3D models produced by Photogrammetry and TLS.

\subsection{Previous Results}

Quality controls the generated products were performed. From these results, by preliminary statistical analysis, it was observed that:

- The quality of phototriangulation process resulted in a mean square error (RMS) of $12 \mathrm{~cm}$ to horizontal and $25 \mathrm{~cm}$ to vertical. This is respectively 1.2 and 2.5 the average GSD defined;

- The quality of point cloud acquired with TLS Optech 3D HD ILRIS to be used in the generation of DTM, resulted in an RMS of $10 \mathrm{~cm}$ for planimetry. The altimetry is still under analyses;

- The quality of point cloud acquired with TLS Faro Focus 3D S, which from it is produced a 3D model of the Church resulted in a $1 \mathrm{~cm}$ RMS for altimetry and planimetry;

- The quality of the cloud quality points created by Photogrammetry is still under review.

\section{CONCLUSIONS AND FUTURE ACTIVITIES}

In this work we present a sequence of procedures that were performed for the production of maps, true-orthophotos and 3D models of the archaeological park of São Miguel Arcanjo, and the ruins that are there. We use a combination of technologies in order to document the cultural heritage and provide the IPHAN information to help them make the most efficient tasks as: preserving they archaeological artifacts, natural resources and other around the park area. With the 3D models generated was possible to know in detail and detect structures were possible at ground level.

In addition to products with accurate geometry in its dimensions, each element present there is georeferenced. This will allow, in addition to monitoring the evolution of deformation structures, conduct other research space reactions among the artifacts found in certain locations. It appears even the possibility of a virtual reconstruction closer to the reality of the time, than approximate models currently available, from antique prints and transcripts describing the locations no longer present structures, knowing now the accurate location of their remains.
Improvements are being implemented in products with new methods of processing, in order to refine the quality. Obtaining results, however, is time consuming, as there are many data acquired with various measurement systems. It is expected that with this, there is an increase of geometric quality positional and visual.

\section{ACKNOWLEDGEMENTS}

The authors would like to express its thanks to: the IPHAN-RS for financing the work through the Cooperation Agreement 01/2013 UFRGS / IPHAN-RS, the REUNI project of the Federal Government, which provided the acquisition of equipment used in this work, UFRGS by disposing of equipment and physical space to carry out this work.

\section{REFERENCES}

Albertz, J., 2001. Albrecht Meydenbauer - pioneer of photogrammetric documentation of the cultural heritage. Proceedings 18th International Symposium CIPA 2001 Potsdam (Germany), (Sep. 2001).

Al-Kheder, S., Al-Shawabkeh, Y., Haala, N., 2009. Developing a documentation system for desert palaces in Jordan using 3D laser scanning and digital photogrammetry. Journal of Archaeological Science, 36(2), 537-546.

Barazzetti, L., Remondino, F., Scaioni, M. 2010. Automation in 3d reconstruction: results on different kinds of close-range blocks. International Archives of Photogrammetry, Remote Sensing and Spatial Information Sciences, Vol. XXXVIII, Part 5, Newcastle upon Tyne, UK.

Bay, H., Ess, A., Tuytelaars, T., Van Gool, L., 2008. SURF: Speeded Up Robust Features. Computer Vision and Image Understanding, 110(3): 346-359.

Bayram, B., Nemli, G., Özkan, T., Oflaz, O. E., Kankotan, B., Çetin, I., 2015. Comparison of laser scanning and photogrammetry and their use for digital recording of cultural monument case study: Byzantine land Walls-Istanbul. ISPRS Annals of the Photogrammetry, Remote Sensing and Spatial Information Sciences, 2(5), 17.

Bleyer, M., Breiteneder, C. Stereo Matching-State-of-the-Art and Research Challenges. In: Farinella, G. M., Battiato, S., Cipolla, R. Advanced Topics in Computer Vision.

Chiabrando, F., Nex, F., Piatti, D., Rinaudo, F., 2011. UAV and RPV systems for photogrammetric surveys in archaelogical areas: two tests in the Piedmont region (Italy). Journal of Archaeological Science, 38(3), 697-710.

Google, 2016. Google Earth Pro. Version 7.1. 2016. Sítio São Miguel Arcanjo, São Miguel das Missões-RS, Brazil. http://www.google.com.

Gordon, S., Lichti, D., Stewart, M., 2001. Application of a high-resolution, ground-based laser scanner for deformation measurements. In Proceedings of 10th International FIG Symposium on Deformation Measurements, Orange, California, USA (pp. 19-22). 
Gordon, S., Lichti, D., Stewart, M., Franke, J., 2003. Structural deformation measurement using terrestrial laser scanners. In Proceedings of 11th International FIG Symposium on Deformation Measurements (p. 8), (May 2003).

Grussenmeyer, P., Landes, T., Voegtle, T., Ringle, K., 2008. Comparison methods of terrestrial laser scanning, photogrammetry and tacheometry data for recording of cultural heritage buildings. ISPRS Arch. Photogramm. Remote Sens, 37, W5.

Herráez, J., Navarro, P., Denia, J., Martín, M., and Rodríguez, J., 2014. Modeling the thickness of vaults in the Church of Santa Maria de Magdalena (Valencia, Spain) with laser scanning techniques. Journal of Cultural Heritage, 10.1016/j.culher. 2013.11.015, 679-686.

IPHAN, 2014a. O IPHAN, Instituto do Patrimônio Histórico e Artístico Nacional (IPHAN), Brazil, http://portal.iphan.gov.br/ pagina/detalhes/872 (10 Jan. 2016).

IPHAN, 2014b. Missões Jesuítas Guaranis - no Brasil, ruínas de São Miguel das Missões (RS), Instituto do Patrimônio Histórico e Artístico Nacional (IPHAN), Brazil, http://portal.iphan.gov.br /pagina/ detalhes/872 (15 Jan. 2016).

Leal, C. F. B., 2009. As Missões da UNESCO no Brasil: Michel Parent. In: Simpósio Nacional de História, 25., 2009, Fortaleza. Anais do XXV Simpósio Nacional de História - História e Ética. Fortaleza: ANPUH, 2009. CD-ROM.

Lerma, J. L., Navarro, S., Cabrelles, M., Villaverde, V., 2010. Terrestrial laser scanning and close range photogrammetry for 3D archaeological documentation: The Upper Palaeolithic Cave of Parpalló as a case study. Journal of Archaeological Science, 37(3), 499-507.
Lowe, D. G., 2004. Distinctive image features from scaleinvariant keypoints. International Journal of Computer Vision, 60(2):91-110.

Lubowiecka, I., Armesto, J., Arias, P., Lorenzo, H., 2009. Historic bridge modelling using laser scanning, ground penetrating radar and finite element methods in the context of structural dynamics. Engineering Structures, 31(11), 26672676.

Remondino, F., Gruen, A., Schwerin, J. von, Eisenbeiss, H., Rizzi, A., Girardi, S. Sauerbier, M., Richards-Rissetto, H., 2009. Multi-sensor 3D documentation of the Maya site of Copan. In: 22nd CIPA Symposium, October 11-15, 2009, Kyoto, Japan.

Staiger, R. 2011. 10 years of terrestrial laser scanning technology, systems and applications. FIG Germany, https://www.fig.net/news/news_2011/geosiberia_april_2011/No vosibirsk_Geosiberia_2011_Paper_Rudolf_Staiger.pdf (Abr. 2011)

Themistocleous, K., Ioannides, M., Agapiou, A., Hadjimitsis, D. G., 2015. The methodology of documenting cultural heritage sites using photogrammetry, UAV, and 3D printing techniques: the case study of Asinou Church in Cyprus. In Third International Conference on Remote Sensing and Geoinformation of the Environment (pp. 953510-953510). International Society for Optics and Photonics.

Yastikli, N., 2007. Documentation of cultural heritage using digital photogrammetry and laser scanning. Journal of Cultural Heritage, 8(4), 423-427. 